\title{
Analisis Pergerakan Harga Saham Untuk Mendeteksi Adanya Noise Atau Kedatangan Informasi Di Bursa Efek Indonesia
}

\author{
Kartini * \\ Kurnia Yuspita **
}

\begin{abstract}
This study aimed to test the presence of noise or the arrival of information between non-trading period returns and trading period with prior periods. The data used are secondary data from the companies listed in LQ45for 2009 and 2011. The sample in this study was103 companies. Analysis tools used to test the hypothesisis auto correlation. Results of this studyindicatethat the price movement of shares between non-trading period and the period oftrading in the stock exchanges in Indonesia caused by noise and arrival information. Correction caused by the noise made during the trading period. Based on company size, sales volume up and down market onditions, the price correction caused by the noise made during the trading period. Unless quintile based on trading volume, because the price correction caused by the noise made during non-trading periods.
\end{abstract}

Keyword: noise, arrival information, firm size, trading volume, up-down market.

* Dosen Fakultas Ekonomi UII

**Alumni Fakultas Ekonomi UII 


\section{Pendahuluan}

Selama ini ekonom di berbagai belahan dunia mencoba menjelaskan teknik pengambilan keputusan secara kuantitatif (dengan pemodelan matematika, statistika, dan ekonometrika) yang mengasumsikan manusia selalu berperilaku rasional. Tetapi pemodelan kuantitatif mulai dipertanyakan beberapa kalangan ketika beberapa kasus keuangan tidak mampu dijelaskan menggunakan teori keuangan standar (Bikhchandani dan Sharma 2001). Maka dari itu Teori Keuangan Keperilakuan (Behaviour Finance) dikembangkan untuk menganalisis bias psikologi yang belum terakomodasi dalam teori keuangan standar.Menurut teori keuangan perilaku, pembeli saham menghendaki agar harga saham yang dibelinya naik sedangkan penjual menginginkan harga saham yang dijualnya mengalami penurunan. Perbedaan pendapat dari penjual dan pembeli saham ini bisa menyebabkan harga yang tercipta tidak stabil. Harga yang tidak stabil bisa membuat pergerakan dari harga saham juga cenderung tidak stabil. -

Pergerakan dari harga saham bisa berarti adanya kedatangan informasi baru atau adanya noise (Huang, et al., 2000). Kedatangan informasi yang baru diantaranya pembagian deviden, tingkat bunga, laba dan pengumuman laporan keuangan perusahaan baik informasi di masa lalu, masa sekarang ataupun informasi yang baru bersifat pendapat yang beredar dalam pasar (Harsono,2003).Sedangkan noise sendiri merupakan fluktusi harga dan volume yang tidak memberikan informasi penting tentang pergerakan harga di pasar (Black, 1986). Fluktuasi harga dan volume yang tidak memberikan informasi ini membuat investor menjadi tidak tepat dalam melakukan penilaian terhadap nilai saham yang sesungguhnya. Pendekatan noise trading mendasarkan pada noise yang 
seakan-akan sebuah kedatangan informasi. Jika banyak noise trading, maka pasar menjadi semakin tidak liquid (Sucahyo, 2004).Fakta yang ada dilapangan menunjukkan bahwa pedagangnoise menempatkan noise dalam harga sekuritas yang diperdagangkan (Sumiyana, 2007).

Penelitian tentang noise dilakukan oleh Black (1986). Dalam penelitiannya yang berjudul 'Noise', Black menyatakan bahwa (noise) adalah perdagangan yang menggangap noise seolah-olah informasi.Noise juga membuat pasar keuangan menjadi mungkin, tetapi juga membuat pasar menjaditidak sempurna.Noise membuat sangat sulit untuk menguji teori-teori praktis atau akademis tentang pasar keuangan rasional. Dengan kata lain, noise menciptakan kesempatan untuk perdagangan yang menguntungkan tetapi pada saat yang sama membuatnya sulit untuk diperdagangkan yang menguntungkan.

Dengan melihat kondisi ini maka studi perilaku dalam bidang manajemen keuangan sangat perlu dilakukan, karena dengan penelitian tersebut dapat diketahui bagaimana perilaku investor (pemodal) dalam ${ }^{-}$ menginvestasikan dananya baik pada sektor riil maupun sektor keuangan. Sejauh pengetahuan peneliti, studi mengenai perilaku investor dalam berinvestasi belum banyak dilakukan di Indonesia. Sehingga penelitian mengenai noise ini sangat perlu dilakukan karena studi ini berupaya untuk melakukan pengungkapan yang berkaitan dengan perilaku investor dalam pasar keuangan di Indonesia.

Terlebih pada pasar keuangan yang masuk dalam kualifikasi emerging market seperti pasar keuangan di Indonesia, perilaku investasinya juga sangat dipengaruhi oleh rumor, yang disebut dengan Noise Trading Behaviour (Asri, 2003). Pasar keuangan digerakkan oleh informasi, tetapi tidak tertutup kemungkinan bahwa dalam proses 
pemaknaan informasi itu ada unsur subjektivitas, emosi dan faktor psikologis lainnya. Untuk itu, ilmu psikologi harus memberikan kontribusi sehingga penelitian keuangan tidak hanya bisa menjawab apa (what) tetapi bisa pula menjelaskan mengapa (why) dan bagaimana (how) secara lebih komprehensif (Asri, 2003).

Sesuai dengan uraian latar belakang maka yang menjadi pokok permasalahan adalah bagaimana pergerakan harga saham antara returnperiode non perdagangan dan return perdagangan dengan periodeperiode sebelumnya dalam Bursa Efek di Indonesia.Tujuan penelitian ini adalah untuk menguji pergerakan harga sahamantara periode non perdagangan dan perdagangan dengan periode-periode sebelumnya dalam Bursa Efek Indonesia.

\section{Kajian Pustaka}

\section{Kedatangan Informasi}

Harga saham dalam pasar modal di Indonesia mencerminkan adanya kedatangan informasi. Bila penyebaran kedatangan informasi berjalan baik maka pelaku pasar dapat membentuk harga yang baru. Sehingga tidak ada pelaku pasar yang dapat memanfaatkan analisis tersebut untuk mendapatkan keuntungan ekstra, yang lebih besar dari keuntungan yang diperoleh pelaku pasar lainnya. Di Indonesia yang pasarnya dalam bentuk efisien setengah kuat membuat harga sekuritas secara penuh mencerminkan (fully reflect) semua informasi yang dipublikasikan (all publicly available information) termasuk informasi di laporan keuangan.

Harga sekuritas secara penuh mencerminkan semua kedatangan informasi yang dipublikasikan (public information) termasuk dalam laporan keuangan seperti pendapatan, deviden, pengumuman stock 
split, pengembangan produk baru, kesulitan keuangan, maupun perubahan data-data akuntansi perusahaan. Pengujiannya atas kecepatan harga sekuritas melakukan penyesuaian (speed of adjustment) terhadap kedatangan informasi baru di pasar modal (Shiller, 1986).

\section{Noise}

Selain mencerminkan kedatangan informasi, dalam harga saham jugamencerminkan noise dari noise trader. Noise trader membuat harga saham cenderung bergerak kembali ke nilainya sepanjang waktu. Semakin jauh harga saham bergerak menjauhi nilainya, maka akan semakin cepat harga saham tersebut bergerak kembali ke nilainya.Menurut Sumiyana (2009), noise trader membentuk taksiran yang salah terutama masalah variansi distribusi perolehan aktiva tertentu. Untuk ketidaktepatan persepsi seperti itu, pedagang noise tidak hanya menghasilkan perolehan lebih tinggi daripada investor rasional tetapi juga bisa bertahan dan mendominasi pasar dalam_kekayaan jangka panjang sekali pun mereka mengambil resiko berlebihan.

Noise merupakan fluktusi harga dan volume yang tidak memberikan informasi penting tentang pergerakan harga di pasar (Black, 1986). Fluktuasi harga dan volume yang tidak memberikan informasi ini membuat investor menjadi tidaktepat dalam penilaian terhadap nilai saham.Noise adalah salah satu faktor penting yang diperhatikan investor karena noịse tingkat tinggi dapat memiliki nilai negatif terhadap pasar modal dan ekonomi, seperti harga efek yang kurang informatif, kurang alokasi modal, risiko tinggi, dan adanya gelembung aset (Hwang, 2004). 
Pendekatannoise tradingmenyatakan bahwa terdapat variabilitas harga yangdiakibatkan oleh perdagangan tak terduga yang tidak berkorelasi denganinformasi valid. Noise trading melihat seakanakannoiseadalahinformasi. Semakin banyak noise trading maka semakin tidak likuid suatu pasar, dalam artisemakin sering perdagangan yang memungkinkan pengamatan harga.Harga saham mencerminkan informasi dari pedagang berbasis informasidannoise darinoise trader.

Perbedaan antara noise dan informasi diindikasikan oleh perbedaan nilai autokorelasi. Nilai autokorelasi yang negatif menandakan adanya noise. Sedang nilai autokorelasi yang positif menandakan adanya kedatangan informasi. Jika kedatangan informasi tersebut hanya mempengarubi satu periode maka nilai autokorelasinya bemilai nol. Akan tetapi apabila pengaruh dari kedatangan informasi tersebut lebih dari satu periode maka nilai autokorelasinya menjadi positif (Sewell, 2009).

-.Dalam penelitian ini, ukuran perusahaan, volume perdagangan dan kondisi pasar digunakan sebagai pengendali dalam uji autokorelasi. Ukuran perusahaan menunjukkan besar kecilnya Experusahaan dilihat dari besar kecilnya modal yang digunakan, total aktiva atau total penjualan yang diperoleh. Volumeperdagangan merupakan ukuran besarnya volume saham tertentu yang diperdagangkan, mengindikasikan kemudahan dalam memperdagangkan saham tersebut. Dari penelitian Huang, Liu dan Fu (2000) menunjukkan bila return pasar positif maka return lebih besar terjadi pada periode perdagangan. Demikian pula, jika return pasar negatif maka return yang terjadi juga lebih negatif pada periode perdagangan. 


\section{Penelitian Terdahulu}

Penelitian terdahulu tentang adanya noise diuji oleh Patricia Chelley dan Steeley (2001) dalam penelitian yang berjudul 'Opening Returns, Noise and Overreaction' yang menyatakan bahwareturnperiode non perdagangan mempunyai volatilitas yang lebih tinggi dan berkorelasi : serial negatif dengan retumperiode perdagangan. Hal ini disebabkan karena adanya overeaction dan noise, sehingga ada perbedaan perilaku return pada returnperiode non perdagangan dan return periode perdagangan. Artinya - $\vec{k}$ esalahan penentuan harga periode non perdagangan dapat dikoreksi pada trading time. Kecenderungannoisedalam periode perdagangan jauh lebih kuatdaripadaperiode non perdagangan, reaksi overreactiondannoisedapat menjelaskanperbedaan dalamperilakuopening dan closing return.Apabila ada noise maka pergerakan harga yang naik pada periode perdagangan diikuti pembalikan harga pada periode non perdagangan dan begitupun sebaliknya. Perbedaan antara noise dan kedatangan informasi terindikasi oleh perbedaan nilai autokorelasi antara periode perdagangan dan periode non perdagangan dengan periode sebelumnya.

Penelitian tentang adanya noisedalam kaitan dengan ukuran perusahaan dan volume perdagangan telah dilakukan oleh Easley dan O'Hara (1987) dalam penelitian yang berjudul 'Price, Trade Size and Information in Securities Markets'. Dalam penelitiannyaEasley dan O'Hara menyatakan bahwa noise membuat perusahaan dengan ukuran perusahaan dan volume perdagangan kecil mempunyai efisiensi produksi rendah, leverage tinggi, tingkat profitabilitas rendah sehingga volatilitas return lebih tinggi dibanding dengan ukuran perusahaan besar dan volume perdagangan besar. 
Penelitian tentang adanya noisedalam kaitan dengan kondisi pasar telah dilakukan oleh Huang et al. (2000) dalam penelitian yang berjudul 'Stock Price Behavior Over Trading and Non Trading Periods : Evidence from The Taiwan Stock Exchange'menyatakan bahwa perilaku harga saham sensitif terhadap kondisi pasar. Hasil penelitiannya menunjukkan bahwa pada return harian terdapat noise pada kondisi pasar yang up market. Sedangkan pada kondisi pasar yang down markettidak menunjukkan gejala terjadinya noise. Hal ini mengindikasikan adanya overreaction pada harga pembukaan.

Selain itu penelitian di pasar modal Indonesia juga telah dilakukan oleh Sumiyana (2007), dalam penelitiannya yang berjudul 'Noise atau Kedatangan Informasi : Sebuah Fenomena Spesifik Perilaku Harga Saham di Pasar Modal Indonesia'. Data yang digunakan adalah data intradaydalam indeks saham LQ 45. Basis pengendalian yang digunakan adalah ukuran perusahaan, volume perdagangan, bentang minta tawar (bid-ask spread), kondisi pasar naik dan turun (up down market) dan kebijakan tick size ( tick size statue).Hasilnya return untuk data intraday (antar periode di dalam hari) mempunyai probabilitas besar jadi noise, sedangkan return untuk interday (antar hari) mempunyai probabilitas besar terjadi kedatangan informasi atau mempunyai kemungkinan kecil terjadi noise.

\section{Hipotesis Penelitian}

Berdasarkan Kajian diatas maka penulis mengajukan hipotesis sebagai berikut :

$\mathrm{H}_{1}$ : Adanya noise atau kedatangan informasi antara return periode non perdagangan dengan periode-periode sebelumnyadi Bursa Efek Indonesia. 
$\mathrm{H}_{2}$ : Adanya noise atau kedatangan informasi antara return periode perdagangan dengan periode-periode sebelumnya di Bursa Efek Indonesia.

\section{Metode Penelitian}

\section{Populasi dan Sampel}

Populasi dan sampel pada penelitian ini adalah perusahaan yang sahamnya termasuk dalam kategori saham yang aktif diperdagangkan.Oleh karena itu, sampel dalam penelitian ini adalah perusahaan-perusahaan yang termasuk dalam Indeks Saham LQ 45 untuk tahun 2009 dan tahun 2011. Indeks Saham LQ 45 dipilih karena perusahaan yang terdaftar didalamnya, berlikuiditas tinggi sehingga mengurangi adanya saham yang tidak aktif baik di sesi pembukaan ataupun sesi penutupan di Bursa Efek Indonesia.

\section{Jenis dan Sumber Data}

Data yang digunakan dalam penelitian ini adalah data sekunder. Data sekunder dalam penelitian ini berupa laporan keuangan tahun 2009 dan 2011 yang telah dipublikasikan.

\section{Variabel-Variabel Penelitian}

Dalam penelitian ini kedatangan informasi dan noise diukur dengan nilai autokorelasi dari pergerakan harga saham. Pengukuran ini dianggap tepat menggambarkan kedatangan informasi ataunoise karena berfokus dalam penghitungan nilai autokorelasi saja. Adapun variabel penelitian yang digunakan dalam penelitian ini adalah :

1) Retum Saham $: \ln \left(P_{t} / P_{t-1}\right)$

2) Ukuran perusahaan : Total Aset Langsung + Total Aset Tidak Langsung 
3) Volume Trading : Volume Penjualan $x$ Harga Penutupan (close) Harian

4) Return Market (Rm) : ln ( P IHSG / P IHSG IH-1 $_{\text {) }}$ )

\section{Metode Analisis Data}

Metode statistik yang digunakan dalam penelitian ini adalah autokorelasi dengan model:

$$
I=\frac{n \sum X Y-\sum X \sum Y}{\left.\sqrt{\left[n \sum X^{2}\right.}-\left(\sum X\right)^{2}\right]\left[n \sum Y^{2}-\left(\sum Y\right)^{2}\right]}
$$

Dimana :

r : Nilai Korelasi

$\Sigma X$ : Jumlah Pengamatan Variabel X (Variabel Independen)

$\Sigma Y$ : Jumlah Pengamatan Variabel Y (Variabel Dependen )

$\mathrm{XY}$ : Jumlah Hasil Perkalian Variabel $X$ dan Variabel $Y$

$\left(\Sigma \mathrm{X}^{2}\right)$ : Jumlah Kuadrat dari Jumlah Pengamatan Variabel X

$\left(\Sigma Y^{2}\right)$ : Jumlah Kuadrat dari Jumlah Pengamatan Variabel $Y$

n : Jumlah Pasangan Pengamatan Variabel $X$ dan Variabel $Y$

\section{Pengujian Hipotesis}

$\mathrm{H}_{0}$ diterima : jika $\mathrm{r}=0$ artinya tidak ada noise dan atau kedatangan informasiatau $\mathrm{T}$ hitung $<\mathrm{T}$ tabeldan signifikansi $>5 \%$ $(0,05)$

$\mathrm{H}_{0}$ ditolak : jika $\mathrm{r} \neq 0$ artinya ada noise dan atau ada kedatangan informasiatau $\mathrm{T}$ hitung $>\mathrm{T}$ tabeldan signifikansi $\leq 5 \%$ $(0,05)$

\section{Hasil Analisis}

\section{Statistika Deskriptif}

Analisis statistik deskriptif terhadap 103 perusahaan dalam Tabel 1 menyajikan data rata-rata, median, variansi, standar deviasi serta nilai maksimum, nilai minimum dan juga skewness return dari periode non 
perdagangan $\left(R_{1}\right)$ dan periode perdagangan $\left(R_{2}\right)$ di Bursa Efek Indonesia. Rata-rata return saham tertinggi terjadi pada total return periode perdagangan (Total $\mathrm{R}_{2}$ ) dengan nilai 0,002 sedangkan rata-rata return saham terendah pada total return periode non perdagangan (Total $\mathrm{R}_{1}$ ) dengan nilai 0,001 .

Tabel 1. Statistik Deskriptif Return Periode Non Perdagangan dan Return Periode Perdagangan

\begin{tabular}{|l|c|c|c|c|c|c|}
\hline \multirow{2}{*}{ Ket } & \multicolumn{2}{|c|}{ Tahun 2009 } & \multicolumn{2}{c|}{ Tahun 2011 } & \multicolumn{2}{c|}{ Total } \\
\cline { 2 - 7 } & $\mathbf{R}_{\mathbf{1}}$ & $\mathbf{R}_{\mathbf{2}}$ & $\mathbf{R}_{\mathbf{I}}$ & $\mathbf{R}_{\mathbf{2}}$ & $\mathbf{R}_{\mathbf{I}}$ & $\mathbf{R}_{\mathbf{2}}$ \\
\hline Jumlah & $\mathbf{1 8 , 3 2}$ & $\mathbf{1 4 , 4 5}$ & $-18,03$ & $\mathbf{1 1 , 7 1}$ & $\mathbf{0 , 7 2 9}$ & $\mathbf{2 6 , 2 1 6}$ \\
\hline Rata-Rata & $\mathbf{0 , 0 0 2}$ & $\mathbf{0 , 0 0 1}$ & $-0,001$ & $\mathbf{0 , 0 0 1}$ & $\mathbf{0 , 0 0 1}$ & $\mathbf{0 , 0 0 2}$ \\
\hline Median & $\mathbf{0 , 0 0 8}$ & $\mathbf{0 , 0 1 5}$ & $\mathbf{0 , 0 2 4}$ & $-0, \mathbf{0 2 4}$ & $\mathbf{0 , 0 3 2}$ & $-0, \mathbf{0 0 9}$ \\
\hline Variansi & $\mathbf{0 , 0 0 1}$ & $\mathbf{0 , 0 0 1}$ & $\mathbf{0 , 0 0 1}$ & $\mathbf{0 , 0 0 1}$ & $\mathbf{0 , 0 0 2}$ & $\mathbf{0 , 0 0 2}$ \\
\hline Std Deviasi & $\mathbf{0 , 0 1 5}$ & $\mathbf{0 , 0 3 4}$ & 0,013 & $\mathbf{0 , 0 2 4}$ & $\mathbf{0 , 0 2 8}$ & $\mathbf{0 , 0 5 8}$ \\
\hline Maksimal & $\mathbf{0 , 1 0 5}$ & $\mathbf{0 , 3 0 8}$ & 0,085 & $\mathbf{0 , 2 2 5}$ & $\mathbf{0 , 1 9 0}$ & $\mathbf{0 , 5 3 3}$ \\
\hline Minimal & $-0,25$ & $-0,274$ & $-0,225$ & $-0,179$ & $-0,350$ & $-0,453$ \\
\hline Skewness & $-0,25$ & $\mathbf{0 , 9 7 8}$ & $-1,496$ & $\mathbf{0 , 3 4 5}$ & $-2,321$ & 1,323 \\
\hline $\mathbf{n}$ & $\mathbf{1 2 4 2 8}$ & $\mathbf{1 2 4 2 8}$ & 12495 & $\mathbf{1 2 4 9 5}$ & 24923 & $\mathbf{2 4 9 2 3}$ \\
\hline
\end{tabular}

\section{Keterangan :}

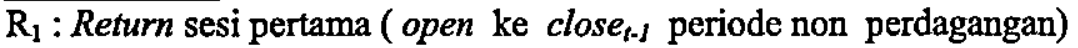

$\mathrm{R}_{2}$ : Return sesi kedua (close ke open periode perdagangan)

Standar deviasi merupakan ukuran penyebaran yang berfungsi untuk mengukur resiko dari data yang diperoleh. Standar deviasi terbesar terjadi pada total return periode perdagangan (Total $\mathbf{R}_{2}$ ) yaitu dengan nilai 0,058. Sedangkan, standar deviasi terendah terjadi pada total return periode non perdagangan (Total $\mathrm{R}_{\mathrm{I}}$ ) dengan nilai 0,028 . Untuk nilai variansi pada total return periode perdagangan (Total $R_{2}$ ) bernilai sama dengan total refurn periode non perdagangan (Total $R_{1}$ ) yaitu 0,002 . Sehingga dapat dikatakan bahwa sébaran data tersebut bervariasi, karena nilai variansinya lebih besar dari 0 (nol).

Skewness merupakan derajat ketidaksimetrisan suatu distribusi. Nilai skewness tertinggi terdapat pada total periode perdagangan (Total 
$R_{2}$ ) yaitu 1,323 dan nilai skewness terendah pada total return periode non perdagangan (Total $R_{1}$ ) yaitu $-2,321$.

\section{Hasil Uji Autokorelasi Tahun 2009 dan Tahun 2011}

Tabel 2. Analisis Komparasi Uji Autokorelasi tahun 2009 dan tahun 2011

T Tabel dengan signifikansi $0,05(5 \%)$ adalah 1.962

\begin{tabular}{|c|c|c|c|c|c|c|c|c|c|c|c|c|c|}
\hline \multirow{2}{*}{$\begin{array}{l}\text { Retura } \\
\text { Period }\end{array}$} & \multirow{2}{*}{ Th } & \multicolumn{3}{|c|}{$\operatorname{Lag} P_{-1}$} & \multicolumn{3}{|c|}{ Lag $\mathbf{P}_{-2}$} & \multicolumn{3}{|c|}{ Lag $P_{-3}$} & \multicolumn{3}{|c|}{ Lag $P_{-1}$} \\
\hline & & $\mathbf{R}$ & t-val & sig & $\mathbf{r}$ & t-val & sig & $\mathbf{R}$ & t-val & sip & $\mathbf{r}$ & t-val & sip \\
\hline \multirow[t]{2}{*}{$\overline{\mathbf{R}_{\mathbf{1}}}$} & ${ }^{\circ} 09$ & 0,119 & $\begin{array}{l}13,36 \\
0^{+}\end{array}$ & $\begin{array}{l}0,00 \\
0\end{array}$ & $\begin{array}{l}0,0 \\
28\end{array}$ & $\begin{array}{l}3,122 \\
+4\end{array}$ & $\begin{array}{l}0,00 \\
2\end{array}$ & $\begin{array}{l}0,00 \\
3\end{array}$ & $\begin{array}{l}0,33 \\
4\end{array}$ & $\begin{array}{l}0,75 \\
7\end{array}$ & 0,077 & $\begin{array}{l}8,609 \\
++\end{array}$ & $\begin{array}{l}0,0 \\
00\end{array}$ \\
\hline & 411 & 0,026 & 2,899 & $\begin{array}{l}0,00 \\
3 \\
\end{array}$ & $\begin{array}{l}0,0 \\
58\end{array}$ & $\begin{array}{l}6,476 \\
+\end{array}$ & $\begin{array}{l}0,00 \\
0\end{array}$ & $\begin{array}{l}0,00 \\
1\end{array}$ & $\begin{array}{l}0,11 \\
1\end{array}$ & $\begin{array}{l}0,89 \\
2\end{array}$ & 0,076 & $\begin{array}{l}8,496 \\
+\end{array}$ & $\begin{array}{l}0,0 \\
00\end{array}$ \\
\hline \multicolumn{2}{|c|}{ TOTAL $\mathbf{R}_{1}$} & 0,083 & $\begin{array}{l}13,14 \\
8^{+} \\
\end{array}$ & $\begin{array}{l}0,00 \\
0 \\
\end{array}$ & $\begin{array}{l}0,0 \\
20 \\
\end{array}$ & $\begin{array}{l}3,158 \\
+\end{array}$ & $\begin{array}{l}0,00 \\
1 \\
\end{array}$ & $\begin{array}{l}0,00 \\
3 \\
\end{array}$ & $\begin{array}{l}0,47 \\
4 \\
\end{array}$ & $\begin{array}{l}0,64 \\
3 \\
\end{array}$ & 0,086 & $\begin{array}{l}13,62 \\
7^{++} \\
\end{array}$ & $\begin{array}{l}0,0 \\
00 \\
\end{array}$ \\
\hline \multirow[t]{2}{*}{$\mathbf{R}_{2}$} & 69 & 0,035 & $\begin{array}{l}3,914 \\
+\end{array}$ & $\begin{array}{l}0,00 \\
0\end{array}$ & $\begin{array}{l}- \\
0,0 \\
49\end{array}$ & $-5,470$ & $\begin{array}{l}0,00 \\
0\end{array}$ & $\begin{array}{l} \\
0,01 \\
8\end{array}$ & $\begin{array}{l} \\
2,01 \\
2\end{array}$ & $\begin{array}{l}0,04 \\
9\end{array}$ & $-0,018$ & $\begin{array}{l}- \\
2,012\end{array}$ & $\begin{array}{l}0,0 \\
44\end{array}$ \\
\hline & 11 & 0,013 & $-1,453$ & $\begin{array}{l}0,14 \\
2\end{array}$ & $\begin{array}{l}- \\
0,0 \\
37\end{array}$ & $\begin{array}{l}- \\
4,133 \\
4 *\end{array}$ & $\begin{array}{l}0,00 \\
0\end{array}$ & $\begin{array}{l} \\
0,02 \\
9\end{array}$ & $\begin{array}{l}- \\
3,24 \\
0\end{array}$ & $\begin{array}{l}0,11 \\
1\end{array}$ & 0,033 & $\begin{array}{l}3,690 \\
++\end{array}$ & $\begin{array}{l}0,0 \\
00\end{array}$ \\
\hline \multicolumn{2}{|c|}{ TOTAL $R_{2}$} & 0,017 & $\begin{array}{l}2,684 \\
+\end{array}$ & $\begin{array}{l}0,00 \\
7\end{array}$ & $\begin{array}{l}- \\
0,0 \\
45\end{array}$ & $\begin{array}{l}- \\
7,097\end{array}$ & $\begin{array}{l}0,00 \\
0\end{array}$ & $\begin{array}{l} \\
0,02 \\
1\end{array}$ & $\begin{array}{l} \\
3,31 \\
4 * 4\end{array}$ & $\begin{array}{l}0,00 \\
1\end{array}$ & $-0,002$ & $-0,316$ & $\begin{array}{l}0,7 \\
95\end{array}$ \\
\hline
\end{tabular}

\section{Keterangan:}

“**t sebagai pertanda terjadinya noise

"t" sebagai pertanda terjadinya kedatangan informasi

*** signifikan negatif pada level $(0,10) ; *$ signifikan negatif pada level $(0,05)$

** signifikan negatif pada level $(0,01)$

++ signifikan positif pada level $(0,10) ;+$ signifikan positif pada level $(0,05)$

+ signifikan positif pada level $(0,01)$

Lag $P_{-1}$, artinya korelasi dengan senjang waktu satu periode sebelumnya

Lag $P_{-2}$, artinya korelasi dengan senjang waktu dua periode sebelumnya

Lag $P_{-3}$, artinya korelasi dengan senjang waktu tiga periode sebelumnya

Lag $P_{-4}$, artinya korelasi dengan senjang waktu empat periode sebelumnya

$\mathbf{R}_{1}$ : Retum sesi pertama (open ke close periode non perdagangan)

$\mathbf{R}_{\mathbf{2}}$ : Retum sesi kedua (close ke open periode perdagangan)

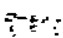

Berdasarkan hasil pengujianyang dapat dilihat dalam Tabel 2pada $\mathbf{R}_{\mathbf{1}}$ return periode non perdagangan yang dikorelasikan dengan lag satu, lag dua dan lag empat yang memiliki nilai autokorelasi positif $(r>0)$ dan signifikan pada level 5\% diketahui bahwa pada $R_{1}$ return periode non perdagangantidak terjadi noise. Hasil ini menunjukkan bahwa Hipotesis I $\left(\mathrm{H}_{1}\right)$ terbukti yaitu tidak terjadinya noise (terjadi kedatangan informasi) 
Kartini \& Kurnia Yuspita, Analisis Pergerakan Harga Saham Untuk Mendeteksi.....

antara return periode non perdagangan dengan periode sebelumnya di Bursa Efek Indonesia.

Sedangkan pada $\mathrm{R}_{2}$ returnperiode perdagangan yang dikorelasikan denganlag dua, lag tiga dan lag empat yang memiliki nilai autokorelasi negatif $(r<0$ ) dan signifikan pada level $5 \%$ diketahui bahwa pada $\mathrm{R}_{2}$ return periode perdagangan terjadi noise. Hasil ini menunjukkan bahwa Hipotesis $2\left(\mathrm{H}_{2}\right)$ terbukti yaitu terjadi noise antara return periode perdagangan dengan periode sebelumnya di Bursa Efek Indonesia.

Dalam penelitian-ini menyajikan bukti yang mendukung konsep $\therefore \quad$ penelitian yang dilakukañoleh Sumiyana (2007)-dan Chelley \& Steeley (2001). Penelitian ini juga membuktikan hipotesis yang menyatakan bahwaadanya noise atau kedatangan informasi antara return periode non perdagangan dan periode perdagangan dengan periode-periode sebelumnya di Bursa Efek Indonesia terbukti valid.

\section{Hasil Uji Autokorelasi Pergerakan Return Saham Berbasis Ukuran Perusahaan}

\begin{tabular}{|c|c|c|c|c|c|c|c|c|c|c|c|c|c|}
\hline \multirow{2}{*}{$\begin{array}{l}\text { Retu } \\
\text { rn } \\
\text { Perio } \\
\text { de }\end{array}$} & \multirow{2}{*}{$\begin{array}{c}\text { Ukuran } \\
\text { Petusah } \\
\text { aan }\end{array}$} & \multicolumn{3}{|c|}{ Lag P.1 } & \multicolumn{3}{|c|}{ Lag $P_{-2}$} & \multicolumn{3}{|c|}{ Lag P, } & \multicolumn{3}{|c|}{ Lag $P_{4}$} \\
\hline & & $\mathbf{R}$ & t-val & sig & $r$ & t-val & sig & $\mathbf{R}$ & t-val & sig & $\mathbf{R}$ & $\begin{array}{c}\text { t- } \\
\text { value }\end{array}$ & $\operatorname{sig}$ \\
\hline \multirow[t]{5}{*}{$\mathbf{R}_{\mathbf{i}}$} & Terkecil & 0,086 & $\begin{array}{l}13,6 \\
27^{++} \\
\end{array}$ & $\begin{array}{l}0,00 \\
0\end{array}$ & $-0,010$ & $-1,579$ & 0,476 & 0,031 & $4,896^{+}$ & 0,026 & 0,058 & 9,171 & 0,00 \\
\hline & $\mathbf{B}$ & 0,061 & $\begin{array}{l}9,64 \\
8^{+4}- \\
\end{array}$ & $\begin{array}{l}0,00 \\
0 \\
\end{array}$ & 0,039 & $\underset{+}{6,16]}$ & 0,005 & $-0,012$ & $-1,894$ & 0,411 . & 0,091 & $\begin{array}{l}14,42 \\
5^{+}\end{array}$ & 0,00 \\
\hline & $\mathbf{C}$ & 0,087 & \begin{tabular}{|l|}
13,7 \\
$86^{* 4}$ \\
\end{tabular} & $\begin{array}{l}, 000 \\
0 \\
\end{array}$ & 0,010 & 1,579 & 0,473 & 0,002 & 0,882 & 0,914 & 0,118 & $\begin{array}{l}18.75 \\
9^{4+}\end{array}$ & 0,00 \\
\hline & $\mathbf{D}$ & 0,096 & $\begin{array}{l}15,2 \\
25 \\
\end{array}$ & $\begin{array}{l}0, \overline{00} \\
0\end{array}$ & 0,014 & 2.210 & 0.328 & 0.000 & 0,000 & 0,989 & 0,072 & $\begin{array}{l}11,39 \\
6^{24}\end{array}$ & 0,00 \\
\hline & Terbesar & 0,091 & $\begin{array}{l}14,4 \\
25^{++} \\
\end{array}$ & $\begin{array}{l}0,00 \\
0 \\
\end{array}$ & 0,052 & $\stackrel{8.220}{\longrightarrow}$ & 0.000 & $-0,012$ & $-1,894$ & 0,394 & $0,0 \overline{92}$ & $\begin{array}{l}14, \overline{88} \\
5^{+}\end{array}$ & 0,00 \\
\hline \multirow[t]{2}{*}{$\mathbf{R}_{\mathbf{2}}$} & Terkecil & 0,012 & $\begin{array}{l}1.89 \\
5\end{array}$ & $\begin{array}{l}0.37 \\
5\end{array}$ & $-0,048$ & $\begin{array}{l}- \\
7,569\end{array}$ & 0,000 & $-0,011$ & $-1,736$ & 0,423 & $-0,007$ & -1.105 & $\begin{array}{l}0,61 \\
8\end{array}$ \\
\hline & B & $0,04 \overline{0}$ & 6,32 & 0,00 & -0.016 & -2.525 & 0.249 & -0.033 & $-5.207^{*}$ & 0.019 & 0.045 & 7,111 & 0.00 \\
\hline
\end{tabular}




\begin{tabular}{|c|c|c|c|c|c|c|c|c|c|c|c|c|}
\hline & & $0^{4+}$ & 5 & & & & & & & & $=$ & 1 \\
\hline C & 0,008 & $\begin{array}{l}1,26 \\
3\end{array}$ & $\begin{array}{l}0.55 \\
7\end{array}$ & $-0,093$ & $\begin{array}{l} \\
14,61 \\
8 * 2\end{array}$ & 0,000 & $-0,021$ & $-3,314$ & 0,144 & 0,008 & 1.263 & $\begin{array}{l}0, \\
9\end{array}$ \\
\hline D & 0,023 & $\begin{array}{l}3,63 \\
2 \\
\end{array}$ & $\begin{array}{l}0,10 \\
3\end{array}$ & $-0,027$ & $-4,261$ & 0,056 & $-0,024$ & -3.788 & 0,089 & $-0,019$ & $-2,999$ & 0 . \\
\hline $\begin{array}{l}\text { Terbesa } \\
\mathbf{r}\end{array}$ & 0,002 & $\begin{array}{l}0,31 \\
6\end{array}$ & $\begin{array}{l}0,88 \\
2\end{array}$ & $-0,036$ & $-5,679$ & 0,013 & $-0,019$ & $-2,999$ & 0,186 & $-0,055$ & $\begin{array}{l}- \\
8.669\end{array}$ & $\begin{array}{l}0, \\
0\end{array}$ \\
\hline
\end{tabular}

T Tabel dengan signifikansi $0,05(5 \%)$ adalah 1.962

“*” sebagai pertanda terjadinya noise

" + " sebagai pertanda terjadinya kedatangan informasi

*** signifikan negatif pada level $(0,10) ;{ }^{*}$ signifikan negatif pada level $(0,05)$

${ }^{* *}$ signifikan negatif pada level $(0,01)$

+++ signifikan positif pada level $(0,10) ;+$ signifikan positif pada level $(0,05)$;

+ signifikan positif pada level $(0,01)$

Lag $P_{-1}$, artinya korelasi dengan senjang waktu satu periode sebelumnya

Lag $P_{-2}$, artinya korelasi dengan senjang waktu dua periode sebelumnya

Lag $\mathrm{P}_{-3}$, artinya korelasi dengan senjang waktu tiga periode sebelumnya

Lag $\mathrm{P}_{-4}$, artinya korelasi dengan senjang waktu empat periode sebelumnya

$R_{1}$ : Return sesi pertama (open ke close periode non perdagangan); $R_{2}$ : Return sesi kedua (close ke open periode perdagangan)

Berdasarkan hasil penelitianyang dapat dilihat dalam Tabel 3 pada $R_{1}$ return periode non perdagangan berbasis ukuran perusahaan, adanya kedatangan informasiyang dibuktikan dengan nilai autokorelasi positif ( $r$ $>0$ ) dan signifikan pada level $5 \%$ untuk ukuran perusahaan Terkecil dikorelasikan dengan lag satu, lag tiga dan lag empat serta ukuran perusahaan B dikorelasikan dengan lag satu, lag dua dan lag empat - kemudian ukuran perusahaan $\mathrm{C}$ dikorelasikan dengan lag satu dan lag empat serta ukuran perusahaan D dikorelasikan dengan lag satu dan-lag empat dan juga untuk ukuran perusahaan Terbesar yang dikorelasikan dengan lag satu, lag dua dan lag empat. Jadi pada $\mathrm{R}_{1}$ return periode non perdagangan berbasis ukuran perusahaan tidak terjadi noise.

Sedangkan, pada $\mathrm{R}_{2}$ return periode perdagangan berbasis ukuran perusahaan adanya noise yang dibuktikan dengan nilai-autokorelasi 
negatif $(\mathrm{r}<0)$ dan signifikan pada level 5\% terjadi pada return periode perdagangan $\left(R_{2}\right)$ berbasis ukuran perusahaan untuk ukuran perusahaan terkecil yang dikorelasikan dengan lag dua serta ukuran perusahaan B dikorelasikan denganlag tiga kemudian ukuran perusahaan Cdikorelasikan denganlag dua dan juga ukuran perusahaan Terbesar dikorelasikan denganlag dua dan lag empat. Jadi pada $\mathrm{R}_{\mathbf{2}}$ return periode perdagangan berbasis ukuran perusahaan terjadi noise.

Dengan demikian, penelitian ini menyajikan bukti yang mendukung penelitian yang dilakukan Sumiyana (2007) yang menyatakan bahwa perilaku harga saham dan noise terhadap ukuran perusahaan yang lebih kecil dibanding dengan ukuran perusahaan yang lebih besar tidak ada bedanya. Tetapi, penelitian ini menyajikan bukti yang berlawanan terhadap penelitian yang dilakukan Huang et al (2000) serta Hadinugroho (2002) yang menyatakan bahwa perilaku harga saham dan noise lebih sensitif terhadap ukuran perusahaan lebih kecil dibanding ukuran perusahaan yang lebih besar.

\section{Hasil Pergerakan Return Saham Berbasis Volume Perdagangan}

Tabel 4. Analisis Komparasi Uji Autokorelasi Berbasis Quintile Volume Perdagangan

\begin{tabular}{|c|c|c|c|c|c|c|c|c|c|c|c|c|c|}
\hline \multirow{2}{*}{$\begin{array}{l}\text { Retarm } \\
\text { Perlod }\end{array}$} & \multirow{2}{*}{$\begin{array}{c}\text { Vol } \\
\text { Perdegen } \\
\text { gag }\end{array}$} & \multicolumn{3}{|c|}{ Lag $P_{-t}$} & \multicolumn{3}{|c|}{ Lag P..2 $_{2}$} & \multicolumn{3}{|c|}{ Lag $P_{-3}$} & \multicolumn{3}{|c|}{ Lag $P_{-A}$} \\
\hline & & $\mathbf{r}$ & t-val & sig & $\mathbf{r}$ & t-val & sig & $\boldsymbol{r}$ & t-val & sig & $\mathbf{r}$ & t-val & sig \\
\hline \multirow[t]{4}{*}{$\overline{\mathbf{R}_{1}}$} & Terkecti & 0,108 & $\begin{array}{l}17,15 \\
0^{++}\end{array}$ & 0,000 & $\begin{array}{l}0,01 \\
0\end{array}$ & $\begin{array}{l}1,57 \\
9\end{array}$ & $\begin{array}{l}0,50 \\
1\end{array}$ & $\begin{array}{l}0,00 \\
1\end{array}$ & $\begin{array}{l}0,15 \\
8\end{array}$ & 0,974 & 0,093 & $\begin{array}{l}14,74 \\
5^{4+}\end{array}$ & $\begin{array}{l}0,00 \\
0\end{array}$ \\
\hline & B & 0,145 & $\begin{array}{l}23,13 \\
5^{++}\end{array}$ & 0,000 & $\begin{array}{l}- \\
0,04 \\
9\end{array}$ & $\begin{array}{l}- \\
7,72 \\
6 * \approx\end{array}$ & $\begin{array}{l}0,00 \\
1\end{array}$ & $\begin{array}{l}0,01 \\
6\end{array}$ & $\begin{array}{l}2,52 \\
6\end{array}$ & 0,259 & 0,075 & $\begin{array}{l}11,87 \\
3^{++}\end{array}$ & $\begin{array}{l}0,00 \\
0\end{array}$ \\
\hline & C & 0,070 & $\begin{array}{l}11,07 \\
8^{++}\end{array}$ & 0,000 & $\begin{array}{l}- \\
0,02 \\
4\end{array}$ & $\begin{array}{l}- \\
3,78 \\
8\end{array}$ & $\begin{array}{l}0,09 \\
3\end{array}$ & $\begin{array}{l}- \\
0,00 \\
7\end{array}$ & $\begin{array}{l}- \\
1,10 \\
5\end{array}$ & 0,627 & 0,044 & $\begin{array}{l}6,953 \\
+\end{array}$ & $\begin{array}{l}0,00 \\
2\end{array}$ \\
\hline & D & 0,040 & $\begin{array}{l}6,320 \\
+4\end{array}$ & 0,005 & $\begin{array}{l}0,05 \\
5\end{array}$ & $\begin{array}{l}8,69 \\
6^{+4}\end{array}$ & $\begin{array}{l}0,00 \\
0\end{array}$ & $\begin{array}{l}-. . \\
0,01\end{array}$ & $\begin{array}{l}- \\
1,89\end{array}$ & 0,403 & 0,087 & $\begin{array}{l}13,78 \\
6^{+1}\end{array}$ & $\begin{array}{l}0,00 \\
0 \\
0,\end{array}$ \\
\hline
\end{tabular}




\begin{tabular}{|c|c|c|c|c|c|c|c|c|c|c|c|c|c|}
\hline & & & & & & & & 2 & 4 & & & & \\
\hline & Terbesar & $\begin{array}{l}- \\
0,005\end{array}$ & $\begin{array}{l}- \\
0,789\end{array}$ & 0,735 & $\begin{array}{l}0,07 \\
6\end{array}$ & $\begin{array}{l}12,0 \\
32^{+\infty}\end{array}$ & $\begin{array}{l}0,00 \\
0\end{array}$ & $\begin{array}{l}0,01 \\
5\end{array}$ & $\begin{array}{l}, 36 \\
8\end{array}$ & 0,302 & 0,083 & $\begin{array}{l}13,14 \\
8^{4+}\end{array}$ & $\begin{array}{l}0,00 \\
0\end{array}$ \\
\hline \multirow[t]{5}{*}{$\overline{\mathbf{R}_{\mathbf{2}}}$} & Terkecil] & 0,045 & $\begin{array}{l}7,111 \\
+\end{array}$ & $\overline{0,002}$ & $\begin{array}{l}- \\
0,02 \\
9\end{array}$ & $\begin{array}{l}- \\
4,57 \\
6\end{array}$ & $\begin{array}{l}0,03 \\
8\end{array}$ & $\begin{array}{l} \\
0,01 \\
6\end{array}$ & $\begin{array}{l}- \\
2,52 \\
5\end{array}$ & 0,259 & $-0,014$ & $-2,210$ & $\begin{array}{l}0,32 \\
4\end{array}$ \\
\hline & $\bar{B}$ & 0,037 & $\begin{array}{l}5,845 \\
+4\end{array}$ & 0,010 & $\begin{array}{l}- \\
0,05 \\
2\end{array}$ & $\begin{array}{l}- \\
8,19 \\
8^{* * *}\end{array}$ & $\begin{array}{l}0,00 \\
0\end{array}$ & $\begin{array}{l}- \\
0,03 \\
5\end{array}$ & $\begin{array}{l}- \\
5,52 \\
2^{*}\end{array}$ & 0,014 & $-0,019$ & $-2,999$ & $\begin{array}{l}0,19 \\
1\end{array}$ \\
\hline & $\mathbf{C}$ & 0,004 & 0,631 & 0,729 & $\begin{array}{l}- \\
0,08 \\
4\end{array}$ & $\begin{array}{l}- \\
13,2 \\
14 * *\end{array}$ & $\begin{array}{l}0,00 \\
0\end{array}$ & $\begin{array}{l}0,01 \\
3\end{array}$ & $\begin{array}{l}2,05 \\
2\end{array}$ & 0,348 & $-0,010$ & $-1,579$ & $\begin{array}{l}0,47 \\
2\end{array}$ \\
\hline & D & $\begin{array}{l}- \\
0,007\end{array}$ & $\begin{array}{l}- \\
1,105\end{array}$ & $0, \overline{617}$ & $\begin{array}{l} \\
0,04 \\
3\end{array}$ & $\begin{array}{l}- \\
6,78 \\
2 *\end{array}$ & $\begin{array}{l}0,00 \\
3\end{array}$ & $\begin{array}{l}- \\
0,05 \\
6\end{array}$ & $\begin{array}{l}- \\
8,82 \\
6^{* *}\end{array}$ & 0,000 & 0,051 & $\begin{array}{l}8,061 \\
+\end{array}$ & $\begin{array}{l}0,00 \\
0\end{array}$ \\
\hline & Terbesar & $\begin{array}{l}- \\
0,028\end{array}$ & $\begin{array}{l}- \\
4,418 \\
*\end{array}$ & 0,048 & $\begin{array}{l}- \\
0,02 \\
1\end{array}$ & $\begin{array}{l}- \\
3,31 \\
4\end{array}$ & $\begin{array}{l}0,13 \\
0\end{array}$ & $\begin{array}{l} \\
0,01 \\
4\end{array}$ & $\begin{array}{l}- \\
2,21 \\
0\end{array}$ & 0,335 & 0,009 & $1,42 I$ & $\begin{array}{l}0,54 \\
6\end{array}$ \\
\hline
\end{tabular}

\section{Keterangan :}

"*" sebagai pertanda terjadinya noise

"+" sebagai pertanda terjadinya kedatangan informasi

*** signifikan negatif pada level $(0,10) ; *$ signifikan negatif pada level $(0,05) ; * *$ signifikan negatif pada level $(0,01)$

+1 signifikan positif pada level $(0,10) ;+$ signifikan positif pada level $(0,05) ;++$ signifikan positif pada level $(0,01)$

Lag $P_{-1}$, artinya korelasi dengan senjang waktu satu periode sebelumnya

Lag $P_{-2}$, artinya korelasi dengan senjang waktu dua periode sebelumnya

Lag $\mathrm{P}_{-3}$, artinya korelasi dengan senjang waktu tiga periode sebelumnya

Lag $\mathrm{P}_{4}$, artinya korelasi dengan senjang waktu empat periode sebelumnya

$\mathbf{R}_{1}:$ : Return sesi pertama (open ke close periode non perdagangan); $\mathbf{R}_{\mathbf{2}}:$ Return sesi kedua (close ke open periode perdagangan)

Berdasarkan hasil penelitianyang dapat dilihat dalam Tabel 4 pada

$\mathrm{R}_{1}$ return periode non perdagangan berbasisvolume perdagangan, adanya kedatangan informasiyang dibuktikan dengan nilai autokorelasi positif ( $\mathrm{r}$ $>0)$ dan signifikan pada level 5\% untuk ukuranTerkecil yang dikorelasikan dengan lag satu dan lag empat serta volume perdagangan B yang dikorelasikan dengan lag satudan lag empat kemudian volume 
perdagangan $\mathrm{C}$ yang dikorelasikan dengan lag satu dan lag empat serta volume perdaganganD yang dikorelasikan dengan lag satu, lag dua dan lag empat dan juga untuk volume perdagangan Terbesar yang dikorelasikan dengan lag dua dan lag empat. Jadi pada $\mathrm{R}_{1}$ return periode non perdagangan berbasis volume perdagangan tidak terjadi noise.

Sedangkan, pada $\mathrm{R}_{2}$ return periode perdagangan berbasis volume perdagangan adanya noise yang dibuktikan dengan nilai autokorelasi negatif $(r<0$ ) dan signifikan pada level $5 \%$ terjadi pada volume perdagangan Terkecil yang dikorelasikan dengan lagdua serta volume perdagangan B yang dikorelasikan dengan lagdua dan lag tiga kemudian volume perdagangan $\mathrm{C}$ yang dikorelasikan dengan lagdua serta volume perdagangan D yang dikorelasikan dengan lag dua dan lag tiga dan juga volume perdagangan Terbesar yang dikorelasikan dengan lagsatu.Jadi pada $R_{2}$ return periode perdagangan berbasis volume perdagangan terjadi noise.

Adanya kedatangan informasi pada periode perdagangan $\left(\mathrm{R}_{2}\right)$ berbasis volume perdagangan untuk volume perdagangan Terkecil yang dikorelasikan dengan lag satu serta volume perdagangan B yang dikorelasikan dengan lag satu kemudian volume perdagangan $\mathrm{C}$ yang dikorelasikan dengan lag satu dan lag empat serta volume perdagangan $\mathrm{D}$ yang dikorelasikan dengan lag empat pada periode sebelumnya. Jadi pada $\mathrm{R}_{2}$ return periode perdagangan berbasis volume perdagangan tidak terjadi noise (terjadi kedatangan informasi).

Dengan demikian, penelitian ini mendukung penelitian yang dilakukan oleh Sumiyana (2007) yang menyatakan bahwa noise terjadi untuk perusahaan bervolume kecil hingga perusahaan bervolume besar dan menyajikan bukti yang berlawanan _térhadap penelitian 'yang . : - - 
dilakukan oleh Huang et al. (2000) yang menyatakan bahwa perilaku harga saham lebih sensitif pada perusahaan bervolume kecil.

Hasil Pergerakan Return Saham Berbasis Kondisi Return Pasar

Tabel 4. Analisis Komparasi Uji Autokorelasi Berbasis Quintile Kondisi Pasar (Up-

Down Market)

\begin{tabular}{|c|c|c|c|c|c|c|c|c|c|c|c|c|c|}
\hline \multirow{2}{*}{$\begin{array}{l}\text { Return } \\
\text { Period }\end{array}$} & \multirow{2}{*}{$\begin{array}{l}\text { Kandis } \\
\text { I Pasar }\end{array}$} & \multicolumn{3}{|c|}{ Lag $P_{-1}$} & \multicolumn{3}{|c|}{ Lag $P_{-2}$} & \multicolumn{3}{|c|}{ Lag $P_{3}$} & \multicolumn{3}{|c|}{ Lag PA } \\
\hline & & $\mathbf{R}$ & $\begin{array}{l}\text { t- } \\
\text { val }\end{array}$ & sig & $\mathbf{r}$ & t-val & sig & $\mathbf{r}$ & t. & sig & $\mathbf{r}$ & t-val & sig \\
\hline$\overline{\mathbf{R}_{\mathbf{1}}}$ & $\begin{array}{l}\text { Up } \\
\text { Marke } \\
\text { t }\end{array}$ & $\begin{array}{l}0 \\
07 \\
5\end{array}$ & $\begin{array}{l}11, \\
873 \\
+\end{array}$ & $\begin{array}{l}0,0 \\
00\end{array}$ & $\begin{array}{l}0,0 \\
34\end{array}$ & $\begin{array}{l}5,370^{+} \\
+\end{array}$ & $\begin{array}{l}0,0 \\
00\end{array}$ & $\begin{array}{l}0,01 \\
2\end{array}$ & $\begin{array}{l}1,8 \\
94\end{array}$ & $\begin{array}{l}0,1 \\
57\end{array}$ & 0,096 & $\begin{array}{l}15,22 \\
5^{+}\end{array}$ & 0,000 \\
\hline & $\begin{array}{l}\text { Down } \\
\text { Marke } \\
\text { t }\end{array}$ & $\begin{array}{l}0, \\
09 \\
3\end{array}$ & $\begin{array}{l}14, \\
745 \\
+*\end{array}$ & $\begin{array}{l}0,0 \\
00\end{array}$ & $\begin{array}{l}0,0 \\
04\end{array}$ & 0,631 & $\begin{array}{l}0,7 \\
07\end{array}$ & $\begin{array}{l}- \\
0,00 \\
8\end{array}$ & $\begin{array}{l}- \\
1,2 \\
63\end{array}$ & $\begin{array}{l}0,3 \\
85\end{array}$ & 0,073 & $\begin{array}{l}11,55 \\
5^{++}\end{array}$ & 0,000 \\
\hline $\mathbf{R}_{\mathbf{2}}$ & $\begin{array}{l}\text { Up } \\
\text { Marke } \\
t\end{array}$ & $\begin{array}{l}0, \\
01\end{array}$ & $\begin{array}{l}1,7 \\
37\end{array}$ & $\begin{array}{l}0,1 \\
78\end{array}$ & $\begin{array}{l}- \\
0,0 \\
45\end{array}$ & $\begin{array}{l}- \\
7,097 \\
*\end{array}$ & $\begin{array}{l}0,0 \\
00\end{array}$ & $\begin{array}{l}0,02 \\
3\end{array}$ & $\begin{array}{l}3,6 \\
32^{+}\end{array}$ & $\begin{array}{l}0,0 \\
07\end{array}$ & $\begin{array}{l}- \\
0,018\end{array}$ & $\begin{array}{l}- \\
2,841 \\
\end{array}$ & 0,029 \\
\hline & $\begin{array}{l}\text { Down } \\
\text { Marke } \\
\text { t }\end{array}$ & $\begin{array}{l}0, \\
02 \\
4\end{array}$ & $\begin{array}{l}3,7 \\
90^{+}\end{array}$ & $\begin{array}{l}0,0 \\
12\end{array}$ & $\begin{array}{l}- \\
0,0 \\
46\end{array}$ & $\begin{array}{l}- \\
7,254 \\
*\end{array}$ & $\begin{array}{l}0,0 \\
00\end{array}$ & $\begin{array}{l}- \\
0,02 \\
0\end{array}$ & $\begin{array}{l}- \\
3,1 \\
57^{*}\end{array}$ & $\begin{array}{l}0,0 \\
39\end{array}$ & 0,019 & $\begin{array}{l}2,999 \\
+\quad\end{array}$ & $\overline{0,049}$ \\
\hline
\end{tabular}

T Tabel dengan signifikansi 0,05 (5\%) adalah 1.962

\section{Keterangan :}

“*” sebagai pertanda terjadinya noise

" + " sebagai pertanda terjadinya kedatangan informasi

*** signifikan negatif pada level $(0,10) ; *$ signifikan negatif pada level $(0,05)$;

** signifikan negatif pada level $(0,01)$

$+1+$ signifikan positif pada level $(0,10) ;+$ signifikan positif pada level $(0,05)$;

+ signifikan positif pada level $(0,01)$

Lag $P_{-1}$, artinya korelasi dengan senjang waktu satu periode sebelumnya Lag $P_{-2}$, artinya korelasi dengan senjang waktu dua periode sebelumnya Lag $P_{-3}$, artinya korelasi dengan senjang waktu tiga periode sebelumnya Lag $\mathrm{P}_{-4}$, artinya korelasi dengan senjang waktu empat periode sebelumnya $\mathrm{R}_{1}$ : Return sesi pertama (open ke close periode non perdagangan)

$\mathrm{R}_{2}$ : Return sesi kedua (close ke open periode perdagangan) 
Berdasarkan hasil penelitian yang dapat dilihat dalam Tabel 5 . pada $R_{1}$ return periode non perdagangan berbasis kondisi return pasar, adanya kedatangan informasiyang dibuktikan dengan nilai autokorelasi positif $(\mathrm{r}>0)$ dan signifikan pada level $5 \%$ untuk kondisi return pasar up market yang dikorelasikan dengan lag satu, lag dua dan lag empat serta kondisi return pasar down market dikorelasikan dengan lag satu dan lag empat.Jadi pada $R_{1}$ return periode non perdagangan berbasis kondisi return pasar tidak terjadi noise.

Sedangkan, pada $\mathrm{R}_{2}$ return periode perdagangan berbasis volume perdagangan adanya noise yang dibuktikan dengan nilai autokorelasi negatif $(r<0)$ dan signifikan pada level $5 \%$ terjadi untuk kondisi return pasar up market yang dikorelasikan dengan lagdua dan lag empat serta kondisi return pasar down market yang dikorelasikan dengan lagdua dan lag tiga maka terdapat noise.Jadi pada $\mathrm{R}_{2}$ return periode perdagangan berbasis kondisi return pasar terjadi noise.

Adanya kedatangan informasi pada periode perdagangan $\left(R_{2}\right)$ berbasis kondisi pasar untuk kondisi return pasar up market yang dikorelasikan dengan lagtiga serta kondisi return pasar down market yang dikorelasikan dengan lag satu dan lag empat.Jadi pada $\mathrm{R}_{2}$ return periode perdagangan berbasis kondisi return pasar tidak terjadi noise (terjadi kedatangan informasi).

Dengan - demikian, penelitian ini menyajikan bukti yangmendukung terhadap pēnelitian yang dilakukan Sumiyana (2007), Chang et al.(1999) dan Huang et al. (2000) yang menyatakan perilaku harga saham sensitif terhadap kondisi pasar.

\section{PEMBAHASAN}

Bedasarkan hasil penelitian, pergerakan harga saham di Bursa Efek Indonesia terdeteksi adanya noise dan kedatangan informasi. Adanya 
noise dan kedatangan informasi terjadi pada return periode non perdagangan tahun 2009 dan tahun 2011 serta Total $R_{1}$ yang dikorelasikan

-.. - dengan lag satu, lag dua dan lag empat. Selain itu, kedatangan informasireturn periode perdagangan $\left(\mathrm{R}_{2}\right)$ tahun 2009 yang dikorelasikan dengan lag satu dan tahun 2011 dikorelasikan- dēngan lag empat serta Total $\mathrm{R}_{2}$ yang dikorelasikan dengan lag satu. Kemudian return periode - perdagangan $\left(\mathrm{R}_{2}\right)$ tahun 2009 dikorelasikan dengan lag tiga dan lag empat serta tahun 2011 dikorelasikan denganlag dua dan juga Total $R_{2}$ dikorelasikan denganlag dua dan lag tiga terdapat noise.

Hasil penelitian ini didukung oleh hasil penelitian sebelumnya yang dilakukan oleh Sumiyana_(2007). Pada penelitian -yang dilakukan Sumiyana (2007),returnpada periode perdagangan mempunyai probabilitas besar terjadi noise, sedangkan return untuk periode non perdagangan mempunyai probabilitas sangat besar terjadi kedatangan informasi (return positif) atau mempunyai kemungkinan sangat kecil . terjadi noise.Dalam penelitian ini menyajikan bukti yang mendukung konsep penelitian yang dilakukan oleh Sumiyana (2007), Fama \& French. (1995) dan Chelley \& Steeley (2001). Penelitian ini juga membuktikan hipotesis yang menyatakan bahwa noise lebih banyak terjadi untuk return periode perdagangan daripada returnperiode non perdagangan.

Dengan demikian, penelitian ini menyajikan bukti' yang mendukung penelitian yang dilakukan Sumiyana (2007) yang menyatakan bahwa perilaku harga saham dan noise terhadap ukuran perusahaan lebih kecil dibanding ukuran perusahaan yang lebih besar tidak ada bedanya. Akan tetapi, penelitian ini menyajikan bukti yang berlawanan terhadap penelitian yang dilakukan Fama \& French (1995), Huang et al (2000) serta Hadinugroho (2002) yang menyatakan bahwa perilaku harga saham 
dan noise lebih sensitif terhadap ukuran perusahaan lebih kecil dibanding dengan ukuran perusahaan yang lebih besar.

Penelitian inijuga mendukung penelitian yang dilakukan oleh Sumiyana (2007) yang menyatakan bahwa noise terjadi untuk perusahaan bervolume kecil hingga perusahaan bervolume besar dan menyajikan bukti berlawanan terhadap penelitian yang dilakukan oleh Huang et al. (2000) menyatakan bahwa perilaku harga saham lebih sensitif pada perusahaan bervolume kecil.Dengan demikian, penelitian ini menyajikan bukti mendukung terhadap penelitian yang dilakukan oleh Sumiyana (2007), dan Huang et al. (2000) menyatakan bahwa perilaku harga saham sensitif terhadap kondisi pasar.

Penelitian ini membuktikan bahwa noise dan kedatangan informasi terjadi di Bursa Efek Indonesia. Dalam penelitian ini, setelah dikendalikan dengan variabel pengontrol ukuran perusahaan, volume perdagangan dan kondisi pasar terjadi noise dan kedatangan informasi pada saat periode perdagangan. Kecuali untuk volume perdagangan, adanya koreksi harga (noise) terjadi pada periode non perdagangan.Kedatangan informasi di Bursa Efek Indonesia ditunjukkan dalam interval waktu harian. Hal ini membuat perilaku harga saham di Bursa Efek Indonesia ketika terjadi koreksi harga (noise) lebih banyak terjadi pada periode perdagangan. 


\section{Kesimpulan}

1. Noise banyak terjadi pada return periode perdagangan.

2. Kedatangan Informasi banyak terjadi pada return periode non perdagangan

\section{Keterbatasan Penelitian dan Saran}

1. Penelitian selanjutnya dapat menggunakan data intraday untuk meneliti volatilitas return dan menambah jumlah sampel dari perusahaan dengan menambah periode dari penelitian. Sehingga, diharapkan bisa lebih menjelaskan tentang noise (kebisingan) dalam perilaku harga saham di Bursa Efek Indonesia.

2. Peneliti yang tertarik untuk melakukan penelitian di bidang yang sama, dapat menggunakan variabel-variabel lain yang diperkirakan akañ berpengaruh terhadap noise dalam perilaku harga saham seperti bentang minta tawar (bid-ask spread)dan kebijakan tike size yang diduga berpengaruh terhadap noise.

3. Selain itu, peneliti hanya melihat adanya noise atau kedatangan informasi pada periode non perdagangan $\left(R_{1}\right)$ dan periode perdagangan $\left(R_{2}\right)$, bukan menguji beda antara noise berbasis ukuran perusahaan, volume perdagangan dan kondisi pasar. 


\section{DAFTAR PUSTAKA}

Asri, Marwan. 2003. "Ketidakrasionalan Investor di Pasar Modal".Pidato Pengukuhan JabatanGuru Besar Pada Fakultas EkonomiUniversitas Gadjah Mada Yogyakarta,tanggal 6 Desember 2003.

Bikchandani S dan Sharma S. 2001. "Herd behavior in financial markets". IMF Staff Papers 47 (3):279.

Black, F. 1986. "Noise". Journal of Finance 41: 529-543.

Chang EC, Cheng JW, dan Khorana A. 2000. "An Examination of Herd Behaviour in Equity Markets: An International Perspective". Journal of Banking and Finance 24:1651-1679.

Chelley, P., and Steeley. 2001. "Opening Returns, Noise and Overreaction". Journal of Financial Research 24 (4): 512-521.

Easley, D., and O'Hara. 1987. "Price, Trade Size and Information in Securities Markets". Journalof Financial Economics 19: 69-90.

Fama, E, F., 1970. " Efficiency Capital Markets a Review of Theory and Empirical Work". Journal of Finance 25: 387-417.

Fama, E., F., and French. 1995. " The Cross Section of Expected Return". Journal of Finance 47: 427-465.

Hadinugroho. 2002. "Pengaruh Beta, Size, Book to Market, Equity and Earnings Yields terhadap Return Saham". Tesis UGM. Tidak Terpublikasi.

Harsono, R.D.B. 2003. "Perdagangan Berbasis Informasi dan Noise, Volume Transaksi Investor Asing dan Domestik dan Volatilitas pasar di BEJ Sejak Liberalisasi Pasar". Tesis UGM . Tidak Terpublikasikan.

Huang, Y. S., D. Y, Liu, and T, W. Fu. 2000. "Stock Price Behaviour Over Trading and Non-Trading Period : Evidence from the Taiwan Stock Exchange". Journal Business and Financial Accounting : 575-602.

Hwang, S., dan Salmon, M. 2004. Market Stress and Herding. Journal of Empirical Finance 11:585-616.

Sewell,M.,V. 2009 "The Application of Intelligent Systems toFinancial Series Analysis". Tesis.

Shiller, R., J. 1998. "Human Behavior and Efficiency of The Financial System". National Bureau of Economic Research Working Paper, No W6375.

Sucahyo, Anang. 2004. "Perilaku Harga Saham Selama Periode perdagangan dan Non Perdagangan ". Tesis UGM. Terpublikasikan. 
Sumiyana. 2007. "Noise atau Kedatangan Informasi : Sebuah Fenomena Spesifik Perilaku Harga Saham di Pasar Modal Indonesia (Study Empiris Berbasis Data Intraday, Bursa Efek Jakarta (1999-2006). Jurnal Ekonomi dan Bisnis Indonesia 22 (3) : 133-161.

Sumiyana. 2009. "Perilaku Harga Pembukaan (Opening Price) : Noise dan / atau Overreaction (Studi Empiris Berbasis Intraday Data, 2006". Jurnal Riset Akuntansi Indonesia 12 : 30-50 